\title{
Farmers' Motivation In Organic Rice Farming In Gempol Village, Karanganom District, Klaten Regency
}

\author{
Indardi ${ }^{1, *}$ and Restu Budi Nugroho ${ }^{1}$ \\ ${ }^{1}$ Universitas Muhammadiyah Yogyakarta, Indonesia
}

\begin{abstract}
Organic rice innovation has several advantages, such as a higher selling price, better health aspect, and environmentally friendly, and more and more farmers are interested in innovating. There is a government policy to develop it. Farmers plant organic rice because they have motivation. This motivation study utilized Maslow's needs theory, intending to describe the motivation of farmers in organic rice farming in Gempol Village, Karanganom, Klaten. The data were analyzed descriptively using scoring techniques, obtained through the census research method, namely interviewing 37 organic rice farmers in Gempol Village. The results revealed that the average score regarding the motivation of organic rice farmers in Gempol Village was 92.39 (67.39\%) from a score range of $25-125$, categorized as "high". In more detail, the motivation needs of physiological, social, appreciation, and self-actualization were all in the high category, while the safety needs belonged to the moderate category. To meet the needs for a sense of security, farmers should invest some of their organic rice income in livestock activities, whether large or small livestock, or poultry.
\end{abstract}

\section{Introduction}

The majority of Indonesians still depend on agriculture for their livelihoods. farmers' production strategies are influenced by technical aspects related to agricultural production and farm structure, differences in farming motivations also play an important role in farmer decision making [1]. Taking decisions to manage resources in a precautionary and responsible manner in order to protect the health and wellbeing of current and future generation and the environment should be top in the priority list of all farmers [2]. According to [3] Agricultural productivity growth is considered a key pathway to resolving poverty and food insecurity issues in developing Africa. Indonesia is located in a tropical area with high rainfall, causing many plants to live in. Efforts to cultivate the land are continuously carried out to make the land quality remains proper to obtain optimal and sustainable results, especially for meeting the needs of staple food (rice). Organic agriculture is one of the most dynamic and rapidly growing sectors of the global food industry. According to [4] Nowadays, many consumers prefer organic food products compared with non organic and usage also increased to an extent that helps to provide unpolluted

\footnotetext{
*Corresponding author: indardi@umy.ac.id
} 
environment. The increasing prevalence of ecologically sustainable products in consumer markets, such as organic produce, are generally assumed to curtail anthropogenic impacts on the environment [5]. Over time, organic agriculture is an approach to sustainable agriculture because it has commercial viability and can provide solutions to health and environmental problems. According to [6] this phenomenon has led the consumers, particularly for uppermiddle income, to consume healthy foods. This type of agriculture is frequently promoted as a strategy to overcome poverty for small-scale marginal producers in developing countries [7]. Research results in [8] suggest that the lack of economic incentives can be an important barrier to conversion to organic farming.

Small-scale farmers in South-East Asia face serious challenges in agricultural productivity, food security and environmental degradation [9]. Excessive use of chemical for agricultural production by means of conventional farming during this period has put forward a question mark on future of sustainability in agriculture [10] Food safety is also becoming an issue in agriculture, along with food security [11]. Organic agriculture is a farming system and an essential solution in land management to avoid environmental damage and land quality degradation. The characteristics of organic agricultural systems are their bio-diversity at soil, crop, field, whole rotation or polyculture, andlandscape level [12]. The farmers' attitude toward environmental concern was the most important reason for adopting organic rice farming [13]. It can be said to be the answer to the problem of the green revolution carried out in the $1960 \mathrm{~s}$, causing reduced soil fertility and environmental damage due to the uncontrolled use of chemical fertilizers and pesticides. The use of chemical pesticides in agriculture has damaged agricultural land, fisheries, fauna, and flora [14]. The green revolution was able to make Indonesia a food self-sufficiency country in 1984, but on the other hand there were negative impacts caused by the green revolution such as the emergence of environmental and social and health problems [15]. According to [16] The development of organic agriculture in Indonesia began in the early 1980s marked by increasing organic agricultural land, and the number of organic producers. According to [17] Go Organic program already released since 2010 by Ministry of Agriculture to increase the implementation of organic farming in Indonesia. Organic agriculture aims to produce food, especially healthy and sustainable rice staple food. It emphasizes the value of its nutritional content, health, rice quality, with consumers generally from the middle to upper economic communities [18]. With organic rice, people can consume healthy and free of chemicals rice. The development of organic agriculture is an effort made to increase farmers' income and improve food security and environmental sustainability [19]. [20] suggested that the government should consider providing direct incentives to organic rice farmers and extension services should support organic farmers to maintain or enhance grain yields.

Rice farmers in Gempol Village, Karanganom District, Klaten Regency have been developing organic agriculture, especially organic rice since 2012. The initial idea of organic rice farming was carried out since the productivity of non-organic rice previously planted had continued to decline every year. Then, farmers began to innovate by planting organic rice. Over time, the area of organic rice land in Gempol Village has increased. In a relatively short period, organic rice farmers in Gempol Village received the Indonesian National Standard (SNI) certificate as Organic Rice producers in 2016. According to [21] Farmers entitled to put the logo "organic" on the packaging marketed and meet the Indonesian National Standard (SNI). Each product is certified organic must record detailed organic products (farm records). It is the reason underlying this research on the motivation of organic farmers in Gempol Village, who, in a short time, were able to achieve the highest achievement, namely obtaining national recognition as an organic rice producer.

Organic farming is one of the several approaches found to meet the objectives of sustainable agriculture [22]. Organic farming is a production system which avoids, or largely excludes, the use of synthetic fertilizers, pesticides, growth regulators, and livestock feed 
additives [23]. Organic agriculture is defined as "a production system that sustains the health of soils, ecosystems and people [24]. According to the [25], rice farming is said so if it meets the following criteria: a) the location of land and storage for production facilities and agricultural equipment is physically separated from non-organic farming, b) seeds cannot be genetically engineered, and there is no linkage with synthetic chemicals or growth regulators, c) growth media or land does not use synthetic chemicals, d) the period of conversion of agricultural land from non-organic to organic agriculture requires 12 months for seasonal crops and 18 months for perennial crops, e) protection of plants against pests does not use synthetic chemicals, but planting system arrangements, vegetable pesticides, biological agents, and other natural materials, and f) production processing must be separated from nonorganic products and do not use materials that contain additives.

The Indonesian government's decision to enter the free market has resulted in the demand to increase various potentials of Indonesian exports, including the potential in the agricultural sector. In terms of export growth, Indonesia is considered very consistent, which can be seen from the land area and the production level in the agricultural sector. The area of agricultural land in Indonesia is considered very large and has a vast number of farmers. In other words, Indonesia can compete with other countries, including in organic agriculture. The lack of social infrastructure to support small-scale farmers becomes paramount as they contend with dilemmas of engaging in pluriactivity, securing reliable labor, and navigating relationship building with consumers and peers for both short-term profits and long-term social capital [26]. This is consistent with a study in india which shows that without government support, the adoption of organic agriculture seems to be a highly challenging task in a situation, where majority of the farmers fall under the small and marginal category [27]. So the government needs to spread awareness about organic farming through proper policy making [28].

Every individual has needs and desires to be fulfilled, which can be a reason or a driving force for someone to achieve it, often referred to as motivation. According to [29], motivation is as self-actualization of individual strengths that can activate and direct behavior, which is the appearance of the interaction between motives and needs with the conditions seen and can function as goals expected by individuals, which runs in a dynamic process. Results reveal that economics motivations, health and safety, and environmental motivations were significantly important drivers in a farmer's decision to convert to organic production [30].

For the farming community to believe that the organic farming system can benefit agricultural and land productivity, it is necessary to raise their awareness. The existence of a growing sense of community awareness can generate a spirit of motivation or desire to adopt land management technologies using organic systems or using natural methods. Extrinsic motivation means that external conditions exert impact on individuals and encourage them to participate [31].The growth of intrinsic motivation in the community is influenced by the drive from within, for example, wanting to meet the basic needs of life, such as clothing, food, shelter, education, and health.

It has been revealed that several individual needs are the driving force for him to achieve them to be satisfied. Maslow's theory of needs states that someone will remain at a certain level until their needs are satisfied; after being satisfied, they will step up to a higher level [32]. There are five levels affecting motivation, among others: a) physiological needs (hunger, thirst, rest, and sex); b) security needs (in terms of physical, mental, psychological, and intellectual); c) social needs (love needs, a sense of belonging), d) appreciation needs (generally reflected in various status symbols) and e) the need for self-actualization (providing opportunities for someone to develop self-potential, thus turning into real abilities). [33] revealed the need for achievement theory. This theory suggests that human motivation to take action varies, following the strength of a person's need for achievement. The need for achievement is the desire to do the best in a difficult and possible task, including overcoming obstacles during the work completion process, with high standards. Reaching 
peak performance for self is oriented to win in competition with other parties by improving one's abilities through the successful application of talents and hard work. According to [34] "Achievement motivation is the seriousness or impetus for someone to do better than what has been made or achieved before or made or achieved by others" conveyed that there are three characteristics of high achievers: a) preference for doing tasks with a moderate degree of difficulty, b) liking situations where performance arises due to their efforts, not other factors (such as luck), and c) wanting feedback on successes and failures.

This study on farmers' motivation in organic rice farming utilized Maslow's theory concerning various motivation theories. This study placed several needs as expressed by Maslow, not as a sequence in how individuals meet their needs, but simultaneously how individuals can fulfill their needs according to their wishes.

\section{Methods}

This research utilized a descriptive method to provide descriptions, pictures, or paintings in a systematic, factual, and accurate manner regarding the facts, properties, and relationships between the investigated phenomena. The descriptive method has a function to describe or provide an overview of the object to be studied through collected data as they are without analyzing and making generally accepted conclusions [35]. This research applied the survey method as the implementation technique. Within the survey, the researcher investigates to obtain facts from the symptoms in the study area and seeks factual information in social, economic, or political institutions from the studied group or area [36]. The research was conducted in Gempol Village, Karanganom, Klaten. The respondents were taken by census on organic rice farmers, amounting to 37 farmers.

\section{Results}

The motivation measurement of organic rice farmers in this study was grouped into five categories: a) very low motivation (with a score range percentage of 0 to less than $20 \%$ ); b) low motivation ( $20 \%$ to less than $40 \%)$; c ) moderate motivation ( $40 \%$ to less than $60 \%$ ); d) high motivation ( $60 \%$ to less than $80 \%)$; and e) very high motivation $(80 \%$ to $100 \%)$. The results disclosed that the motivation of farmers in organic rice farming in Gempol Village belonged to the "high" category, with an average score of $92(73.6 \%)$, which was in the estimated score of $85_{-}<\mathrm{x}<105$, as presented in the Table. 1, meaning that farmers had high motivation in running organic rice farming in Gempol Village. The maximum number of respondents have positive attitude and interested towards organic farming practices [37].

Table 1. Acquisition of scores and motivation categories

\begin{tabular}{|c|c|c|}
\hline Total Score Range & Score Acquisition & Motivation Category \\
\hline $25-125(0 \%-100 \%)$ & $92.39(67.39 \%)$ & High \\
\hline
\end{tabular}

Undoubtedly, most respondents, 28 out of 37 farmers (75\%), chose the "high" motivation category. A complete description of the frequency distribution of the scores regarding the category of farmer motivation in organic rice farming in Gempol Village is presented in Table 2. Based on the frequency distribution dominated by the high category, it can be interpreted that the average motivation of farmers in running organic rice farming in Gempol village was relatively good. The results revealed that none of the organic rice farmers had low or very low motivation. Moreover, there were only seven farmers whose motivation was in the moderate category. 
Table 2. Frequency distribution of organic farmers' scores

\begin{tabular}{|c|c|c|c|}
\hline \multirow{2}{*}{ No } & Class & Score Range & $\begin{array}{c}\text { Frequency } \\
\text { (people) }\end{array}$ \\
\cline { 2 - 3 } & $25 \geq \times<45$ & Category & 0 \\
\hline 1 & $45 \geq \times<65$ & Low & 0 \\
\hline 2 & $65 \geq \times<85$ & Moderate & 7 \\
\hline 3 & $85 \geq \times<105$ & High & 28 \\
\hline 4 & $105 \geq \times \leq 125$ & Very high & 2 \\
\hline 5 & Total & & 37 \\
\hline \multicolumn{2}{|l}{}
\end{tabular}

A further description of the research results on the motivation of organic farmers regarding the fulfillment of their respective needs, both physiological, safety, social, appreciation, and self-actualization needs, is depicted in Table 3.

Table 3. The motivation of organic rice farmers in fulfilling their respective needs

\begin{tabular}{|c|c|c|c|}
\hline \multirow{2}{*}{ Needs } & \multicolumn{2}{|c|}{ Score } & \multirow{2}{*}{ Category } \\
\hline & Score Range (\%) & Score Acquisition (\%) & \\
\hline 1.Physiological & $5-25(0-100)$ & $18.15(65.75)$ & High \\
\hline 2.Safety & $5-25(0-100)$ & $17.06(60.30)$ & High \\
\hline 3.Social & $5-25(0-100)$ & $19.99(74.95)$ & High \\
\hline 4.Appreciation & $5-25(0-100)$ & $19.68(73.40)$ & High \\
\hline $\begin{array}{l}\text { 5.Self- } \\
\text { Actualization }\end{array}$ & $5-25(0-100)$ & $17.51(62.55)$ & High \\
\hline Total & $5-125(0-100)$ & $92.39(67.39)$ & High \\
\hline
\end{tabular}

Table 3 indicates that the high motivation of organic rice farmers in Gempol Village was driven by the desire to meet all their needs. The motivation to fulfill social needs obtained the highest score, signifying the good collegial culture, togetherness, and cooperation of the Javanese people, especially the farming communities in Gempol Village, Karanganom, Klaten. The score in the "high" motivation category in fulfilling various needs (physiological, security, social, appreciation, and self-actualization) depicted that they could meet their various needs through organic rice farming. Farmers' motivation to fulfill their various physiological, security, social, appreciation, and self-actualization needs provided a slightly varied picture.

\subsection{The Motivation of Farmers in Fulfilling Physiological Needs}

Physiological needs are the most basic ones in human life and the earliest to meet. In this study, physiological needs are related to the extent to which farmers' income from organic rice farming can meet the needs of food, clothing, and shelter to sustain daily life. Farmers believed that they could meet the physiological needs by running organic rice farming because there is considerable government attention, especially through field schools, thus motivating them to farm organic rice. The [38] analysis confirmed that field school attendance increases felt community acceptance and facilitates the satisfaction of the belongingness need. Table 4 provides an overview of how organic rice farmers were motivated to meet their physiological needs. The following data are the physiological needs of organic rice farmers in Gempol Village.

Table 4 depicts that the motivation of organic rice farmers in meeting physiological needs in Gempol Village was in the "high" category with an average score of 3.6. The most basic physiological needs are food, followed by clothing. In line with the study results, the motivation of organic rice farmers in meeting "food needs" obtained the highest score, with 
4.51 and belonged to the "very high" motivation category. Food is the primary need of every human being that must be met to survive. The second highest score was meeting the "clothing needs" with 3.89 and was in the "high" motivation category. Meanwhile, the lowest score was the motivation of organic rice farmers to fulfill "shelter needs" with 2.78 and was the "moderate" category, meaning that meeting such needs were deemed unimportant and not urgent. Most organic rice farmers have owned houses inherited from their parents for a long time. In fulfilling the shelter needs, they only made minor renovations to the damaged part of the house, carried out occasionally a year.

Table 4. The motivation of organic rice farmers in meeting physiological needs

\begin{tabular}{|c|c|c|c|c|c|c|c|}
\hline No & $\begin{array}{c}\text { Physiological } \\
\text { Needs } \\
\end{array}$ & $\begin{array}{c}\text { Score } \\
\text { Category }\end{array}$ & $\begin{array}{l}\text { Score } \\
\text { Range }\end{array}$ & $\begin{array}{l}\text { Number } \\
\text { (people) }\end{array}$ & $\begin{array}{c}\text { Percentage } \\
(\%)\end{array}$ & $\begin{array}{c}\text { Average } \\
\text { Score }\end{array}$ & $\begin{array}{c}\text { Motivation } \\
\text { Category }\end{array}$ \\
\hline \multirow{5}{*}{1} & \multirow{5}{*}{ Food } & $\begin{array}{l}\text { Very Less } \\
\text { Motivated }\end{array}$ & 1 & 0 & 0 & \multirow{5}{*}{4.51} & \multirow{5}{*}{ Very High } \\
\hline & & $\begin{array}{c}\text { Less } \\
\text { Motivated }\end{array}$ & 2 & 0 & 0 & & \\
\hline & & Neutral & 3 & 0 & 0 & & \\
\hline & & Motivated & 4 & 18 & 48.7 & & \\
\hline & & $\begin{array}{c}\text { Very } \\
\text { Motivated }\end{array}$ & 5 & 19 & 51.3 & & \\
\hline & & Total & & 37 & 100 & & \\
\hline \multirow{5}{*}{2} & \multirow{5}{*}{ Clothing } & $\begin{array}{l}\text { Very Less } \\
\text { Motivated }\end{array}$ & 1 & 0 & 0 & \multirow{5}{*}{3.89} & \multirow{5}{*}{ High } \\
\hline & & $\begin{array}{c}\text { Less } \\
\text { Motivated }\end{array}$ & 2 & 0 & 0 & & \\
\hline & & Neutral & 3 & 10 & 27.1 & & \\
\hline & & Motivated & 4 & 21 & 56.7 & & \\
\hline & & $\begin{array}{c}\text { Very } \\
\text { Motivated }\end{array}$ & 5 & 6 & 16.2 & & \\
\hline & & Total & & 37 & 100 & & \\
\hline \multirow{5}{*}{3} & \multirow{5}{*}{ Shelter } & $\begin{array}{l}\text { Very Less } \\
\text { Motivated }\end{array}$ & 1 & 1 & 2.7 & \multirow{5}{*}{2.78} & \multirow{5}{*}{ Moderate } \\
\hline & & $\begin{array}{c}\text { Less } \\
\text { Motivated }\end{array}$ & 2 & 13 & 35.1 & & \\
\hline & & Neutral & 3 & 17 & 46 & & \\
\hline & & Motivated & 4 & 5 & 13.5 & & \\
\hline & & $\begin{array}{c}\text { Very } \\
\text { Motivated }\end{array}$ & 5 & 1 & 2.7 & & \\
\hline & & Total & & 37 & 100 & & \\
\hline \multirow{6}{*}{4} & \multirow{5}{*}{ Sudden Needs } & $\begin{array}{l}\text { Very Less } \\
\text { Motivated }\end{array}$ & 1 & 0 & 0 & \multirow{5}{*}{3.46} & \multirow{5}{*}{ Moderate } \\
\hline & & $\begin{array}{c}\text { Less } \\
\text { Motivated }\end{array}$ & 2 & 2 & 5.4 & & \\
\hline & & Neutral & 3 & 16 & 43.2 & & \\
\hline & & Motivated & 4 & 19 & 51.4 & & \\
\hline & & $\begin{array}{c}\text { Very } \\
\text { Motivated }\end{array}$ & 5 & 0 & 0 & & \\
\hline & & Total & & 37 & 100 & & \\
\hline \multirow{4}{*}{5} & \multirow{4}{*}{$\begin{array}{l}\text { Cost of } \\
\text { education }\end{array}$} & $\begin{array}{l}\text { Very Less } \\
\text { Motivated }\end{array}$ & 1 & 0 & 0 & \multirow{4}{*}{3.51} & \multirow{4}{*}{ High } \\
\hline & & $\begin{array}{c}\text { Less } \\
\text { Motivated }\end{array}$ & 2 & 5 & 13.5 & & \\
\hline & & Neutral & 3 & 8 & 21.6 & & \\
\hline & & Motivated & 4 & 24 & 64.9 & & \\
\hline
\end{tabular}




\begin{tabular}{|c|c|c|c|c|c|c|c|}
\hline No & $\begin{array}{c}\text { Physiological } \\
\text { Needs }\end{array}$ & $\begin{array}{c}\text { Score } \\
\text { Category }\end{array}$ & $\begin{array}{c}\text { Score } \\
\text { Range }\end{array}$ & $\begin{array}{c}\text { Number } \\
(\text { people) }\end{array}$ & $\begin{array}{c}\text { Percentage } \\
(\boldsymbol{\%})\end{array}$ & $\begin{array}{c}\text { Average } \\
\text { Score }\end{array}$ & $\begin{array}{c}\text { Motivation } \\
\text { Category }\end{array}$ \\
\hline & $\begin{array}{c}\text { Very } \\
\text { Motivated }\end{array}$ & 5 & 0 & 0 & & \\
\hline & Total & & $\mathbf{3 7}$ & $\mathbf{1 0 0}$ & & \\
\hline & & & & $\mathbf{3 . 6}$ & High \\
\hline
\end{tabular}

Score Category:

Very Low: $1.0-1.8$

Low: $1.9-2.6$

Moderate: $2.7-3.4$

High: 3.5 - 4.2

Very High: $4.3-5.0$

Organic rice farmers in Gempol Village argued that organic rice farming is more promising than the conventional one. They revealed that the yield of organic rice farming was getting more productive because it did not require a massive cost like conventional rice. Being sustainable, organic rice farming has long-term prospects. Moreover, this rice farming can keep soil conditions stable for decades, thereby maintaining soil texture, aeration, and fertility.

\subsection{The Motivation of Farmers in Fulfilling Security Needs}

Table 5. The motivation of organic rice farmers in fulfilling security needs

\begin{tabular}{|c|c|c|c|c|c|c|c|}
\hline No & $\begin{array}{c}\text { The need for } \\
\text { security }\end{array}$ & Score Category & $\begin{array}{l}\text { Score } \\
\text { Range }\end{array}$ & $\begin{array}{l}\text { Number } \\
\text { (people) }\end{array}$ & $\begin{array}{c}\text { Percentage } \\
(\%)\end{array}$ & $\begin{array}{c}\text { Average } \\
\text { Score }\end{array}$ & $\begin{array}{l}\text { Motivation } \\
\text { Category }\end{array}$ \\
\hline \multirow{6}{*}{1} & \multirow{5}{*}{$\begin{array}{l}\text { Old Age } \\
\text { Supplies }\end{array}$} & $\begin{array}{c}\text { Very Less } \\
\text { Motivated } \\
\end{array}$ & 1 & 0 & 0 & \multirow{5}{*}{3.22} & \multirow{5}{*}{ Moderate } \\
\hline & & Less Motivated & 2 & 5 & 13.5 & & \\
\hline & & Neutral & 3 & 22 & 59.5 & & \\
\hline & & Motivated & 4 & 7 & 18.9 & & \\
\hline & & Very Motivated & 5 & 3 & 8.1 & & \\
\hline & & Total & & 37 & 100 & & \\
\hline \multirow{6}{*}{2} & \multirow{5}{*}{ Savings } & $\begin{array}{l}\text { Very Less } \\
\text { Motivated }\end{array}$ & 1 & 0 & 0 & \multirow{5}{*}{3.95} & \multirow{5}{*}{ High } \\
\hline & & Less Motivated & 2 & 1 & 2.7 & & \\
\hline & & Neutral & 3 & 2 & 5.4 & & \\
\hline & & Motivated & 4 & 32 & 86.5 & & \\
\hline & & Very Motivated & 5 & 2 & 5.4 & & \\
\hline & & Total & & 37 & 100 & & \\
\hline \multirow{6}{*}{3} & \multirow{5}{*}{$\begin{array}{l}\text { Business } \\
\text { Capital }\end{array}$} & $\begin{array}{l}\text { Very Less } \\
\text { Motivated } \\
\end{array}$ & 1 & 1 & 2.7 & \multirow{5}{*}{2.35} & \multirow{5}{*}{ Low } \\
\hline & & Less Motivated & 2 & 25 & 67.6 & & \\
\hline & & Neutral & 3 & 8 & 21.6 & & \\
\hline & & Motivated & 4 & 3 & 8.1 & & \\
\hline & & Very Motivated & 5 & 0 & 0 & & \\
\hline & & Total & & 37 & 100 & & \\
\hline \multirow{6}{*}{4} & \multirow{5}{*}{$\begin{array}{c}\text { Children } \\
\text { Pocket Money }\end{array}$} & $\begin{array}{l}\text { Very Less } \\
\text { Motivated }\end{array}$ & 1 & 0 & 0 & \multirow{5}{*}{3.97} & \multirow{5}{*}{ High } \\
\hline & & Less Motivated & 2 & 0 & 0 & & \\
\hline & & Neutral & 3 & 4 & 10.8 & & \\
\hline & & Motivated & 4 & 30 & 81.1 & & \\
\hline & & Very Motivated & 5 & 3 & 8.1 & & \\
\hline & & Total & & 37 & 100 & & \\
\hline \multirow[t]{2}{*}{5} & \multirow[t]{2}{*}{ Health Costs } & $\begin{array}{l}\text { Very Less } \\
\text { Motivated }\end{array}$ & 1 & 0 & 0 & \multirow[t]{2}{*}{3.57} & \multirow[t]{2}{*}{ High } \\
\hline & & Less Motivated & 2 & 0 & 0 & & \\
\hline
\end{tabular}




\begin{tabular}{|l|c|c|c|c|c|c|c|}
\hline & Neutral & 3 & 16 & 43.2 & & \\
\cline { 3 - 5 } & Motivated & 4 & 21 & 56.8 & & \\
\cline { 3 - 7 } & Very Motivated & 5 & 0 & 0 & & \\
\hline & Total & & $\mathbf{3 7}$ & $\mathbf{1 0 0}$ & & \\
\hline
\end{tabular}

Score Category:

Very Low: $1-1.8$

Low: 1.9 - 2.6

Moderate: 2.7 - 3.4

High: $3.5-4.2$

Very High: 4.3 - 5

Security needs can take the form of a desire for protection against physical harm (fire hazard, or criminal attack), economic certainty, preference for the introduced and away from the unknown, and world order and predictability [39]. In this study, security needs dealt with farmers obtaining the results from organic rice farming to meet the needs of life and savings for old age. If they can meet this need, it will be an essential factor in influencing their motivation to run organic rice farming. The needs for a sense of security for organic rice farmers in Gempol Village are presented in Table 5.

Table 5 illustrates that the motivation for the security needs of organic rice farmers in Gempol Village belonged to the "moderate" category, with an average score of 3.4. They were relatively less motivated in meeting the needs of business capital and old age. The low motivation of organic rice farmers to meet the need for "business capital" (score: 2.35) indicated that they lack the motivation to grow and develop (growth). Farmers lacked the motivation for the achievement need to improve their economic life further. These farmers were economically satisfied with the existing conditions. It is depicted in them prioritizing their social life (motivation to fulfill social needs had the highest score) rather than improving their personal and family economic life.

Organic rice farmers in Gempol Village were more motivated to fulfill their real daily needs, which was pocket money for children, obtaining the highest score with 3.97 and belonging to the "high" motivation category. They were then motivated to fulfill their savings needs (obtaining a score of 3.95 and the category of motivation was "high"), which could be taken at any time to fulfill their other needs, such as health.

\subsection{The Motivation of Farmers in Fulfilling Social Needs}

An individual desire to belong to a specific group, socialize with others, be accepted by his peers, share and accept friendliness are several social needs in one's life [40]. Social needs in this study dealt with the relationship between farmers' interactions with the social environment in the community, whether farmers farming organic rice were influenced by the community or from their own willingness. Table 6 shows the activation of organic rice farmers in Gempol Village to meet social needs, obtaining an average score of 4.0, and was in the "high" category. It means that organic rice farmers in this village had a strong orientation in their social life. Social needs are the fundamental values of life as a member of society, according to the organic farmers in Gempol Klaten, which is part of the Javanese culture with strong collegial values. These farmers had a good life value in building social relationships with the people in their environment. The motivation for fulfilling social needs was prominent in three activities, namely motivation to meet the need for "interacting with other people", "expanding social relationships," and "frequent cooperation". The motivation to meet the need for "interacting with other people" obtained the highest score of 4.78 and was in the "very high" motivation category. It means that organic rice farmers in Gempol Village, in carrying out organic rice farming or other social activities, frequently "interact 
with other people" around them to discuss various problems regarding the farming and other social problems. The interaction frequently occurring was when the farmers were in the land because almost half of them cultivate the fields. Thus, the people frequently met by organic farmers were fellow farmers.

Table 6. The motivation of organic rice farmers in meeting social needs

\begin{tabular}{|c|c|c|c|c|c|c|c|}
\hline No & Social Needs & Score Category & $\begin{array}{l}\text { Score } \\
\text { Range } \\
\end{array}$ & $\begin{array}{l}\text { Number } \\
\text { (people) }\end{array}$ & $\begin{array}{c}\text { Percentage } \\
(\%)\end{array}$ & $\begin{array}{c}\text { Average } \\
\text { Score }\end{array}$ & $\begin{array}{c}\text { Motivation } \\
\text { Category }\end{array}$ \\
\hline \multirow{6}{*}{1} & \multirow{5}{*}{$\begin{array}{l}\text { Interacting With } \\
\text { Others }\end{array}$} & $\begin{array}{l}\text { Very Less } \\
\text { Motivated } \\
\end{array}$ & 1 & 0 & 0 & \multirow{5}{*}{4.78} & \multirow{5}{*}{ Very High } \\
\hline & & Less Motivated & 2 & 0 & 0 & & \\
\hline & & Neutral & 3 & 0 & 0 & & \\
\hline & & Motivated & 4 & 8 & 21.6 & & \\
\hline & & Very Motivated & 5 & 29 & 78.4 & & \\
\hline & & Total & & 37 & 100 & & \\
\hline \multirow{6}{*}{2} & \multirow{6}{*}{$\begin{array}{c}\text { Expanding } \\
\text { Social Relations }\end{array}$} & $\begin{array}{l}\text { Very Less } \\
\text { Motivated }\end{array}$ & 1 & 0 & 0 & \multirow{5}{*}{4.65} & \multirow{5}{*}{ Very High } \\
\hline & & Less Motivated & 2 & 0 & 0 & & \\
\hline & & Neutral & 3 & 1 & 2.7 & & \\
\hline & & Motivated & 4 & 11 & 29.7 & & \\
\hline & & Very Motivated & 5 & 25 & 67.6 & & \\
\hline & & Total & & 37 & 100 & & \\
\hline \multirow{6}{*}{3} & \multirow{5}{*}{$\begin{array}{l}\text { Collaborating } \\
\text { With Others }\end{array}$} & $\begin{array}{l}\text { Very Less } \\
\text { Motivated }\end{array}$ & 1 & 0 & 0 & \multirow{5}{*}{3.35} & \multirow{5}{*}{ Moderate } \\
\hline & & Less Motivated & 2 & 3 & 8.1 & & \\
\hline & & Neutral & 3 & 22 & 59.5 & & \\
\hline & & Motivated & 4 & 8 & 21.6 & & \\
\hline & & Very Motivated & 5 & 4 & 10.8 & & \\
\hline & & Total & & 37 & 100 & & \\
\hline \multirow{6}{*}{4} & \multirow{6}{*}{$\begin{array}{c}\text { Frequent } \\
\text { Cooperation }\end{array}$} & $\begin{array}{l}\text { Very Less } \\
\text { Motivated } \\
\end{array}$ & 1 & 0 & 0 & \multirow{5}{*}{4.16} & \multirow{5}{*}{ Moderate } \\
\hline & & Less Motivated & 2 & 0 & 0 & & \\
\hline & & Neutral & 3 & 0 & 0 & & \\
\hline & & Motivated & 4 & 31 & 83.8 & & \\
\hline & & Very Motivated & 5 & 6 & 16.2 & & \\
\hline & & Total & & 37 & 100 & & \\
\hline \multirow{6}{*}{5} & \multirow{5}{*}{$\begin{array}{l}\text { Information } \\
\text { from other } \\
\text { farmer groups }\end{array}$} & $\begin{array}{l}\text { Very Less } \\
\text { Motivated } \\
\end{array}$ & 1 & 0 & 0 & \multirow{5}{*}{3.03} & \multirow{5}{*}{ Moderate } \\
\hline & & Less Motivated & 2 & 11 & 29.8 & & \\
\hline & & Neutral & 3 & 15 & 40.5 & & \\
\hline & & Motivated & 4 & 10 & 27 & & \\
\hline & & Very Motivated & 5 & 1 & 2.7 & & \\
\hline & & Total & & 37 & 100 & & \\
\hline \multicolumn{3}{|c|}{ Total Average Score } & & & & 4.0 & High \\
\hline
\end{tabular}

Score Category:

Very Low: $1.0-1.8$

Low: $1.9-2.6$

Moderate: $2.7-3.4$

High: 3.5 - 4.2

Very High: $4.3-5.0$

Furthermore, "expanding social relations" was another social needs obtaining the secondhighest score with 4.65. In their busy life as organic rice farmers, it turned out that the farmers had the willingness to expand their social relationships beyond their fellow farmers. It 
indicated that social needs were considered very important for the life of organic rice farmers. There is a proverb in Javanese culture saying "rugi sak thak, bathi sanak" (little material loss but gain in friendship). For the sake of maintaining harmonious social relations with the community, farmers were willing to lose economically as long as they still had many friends, relatives, and continued to have good relationships with others. The motivation for meeting the social needs for "frequent cooperation" activities was also in the category of "high" motivation, with a score of 4.16, it did not belong to the "very high" category of motivation. However, it obtained a score close to the upper limit (4.2), signifying that the culture of cooperation was still thriving in organic rice farming communities. Indeed, there has been a shift in the value of mutual assistance, not as close as in the past.

Meanwhile, the lowest score was found in seeking "information from other farmer groups" with a score of 3.03 and belonged to the "moderate" category. It explained that organic rice farmers did not want to bother other parties in running the farming. Moreover, they had a group assigning to obtain information about organic rice farming.

\subsection{The motivation of Farmers in Fulfilling the Need for Appreciation}

Appreciation needs are for self-respect and recognition from the environment. It is also related to the reputation of an individual or respect from other parties, even the needs for status, recognition, appreciation for himself, and respect given by other parties [41]. Motivation in fulfilling the needs for appreciation in this study referred to the motivation of organic rice farmers in Gempol Village in fulfilling farmers' needs for achievement, recognition, and respect in their community. The results revealed that the activities of organic rice farmers in this village had the most varied motivations in fulfilling appreciation needs, starting from the "low" to the "very high" category of motivation. Table 7 provides an overview of the diversity of motivations for organic rice farmers in Gempol Village in fulfilling appreciation needs.

Table 7 shows that the motivation for the appreciation needs of organic rice farmers in Gempol Village was in the "high" category with an average score of 3.9. It means that in carrying out organic rice farming, farmers wanted to get recognition from the community. Interestingly, farmers' motivations in fulfilling appreciation needs, viewed from their respective activities, were very diverse. Fulfilling the need "pride" received the highest score with 4.84, and was in "very high" motivation, indicating their pride in being organic rice farming. A sense of pride arose as farmers had their achievements, and many parties recognized them. The extraordinary pride felt by organic rice farmers in Gempol Village was that in 2016 as they obtained the SNI certificate (Indonesian National Standard) as a producer of organic rice. It is a recognition and is a very proud achievement at the national level (not an achievement at the district or provincial level). It illustrates their very high need for achievement. It is also depicted from the acquisition of a close to perfect score of 5. It was where $86.5 \%$ (32 people) of organic rice farmers belonged to the "highly motivated" category. Another interesting thing related to the motivation of farmers in fulfilling the need for appreciation was the activity of "getting to know new technology" being in the "very high" motivation category with a score of 4.32 , an ideal farmer's mental condition.

They had a very high sense of pride for achievement. On the other hand, they also had a sense of "wanting to know new technology" of organic rice and a strong will to implement it by farming organic rice. Therefore, with the mental condition of the farmers, it is not surprising that organic rice farmers in Gempol Village received the national title "SNI certificate as organic rice producer", which is their best achievement. Undoubtedly, it was inseparable from farmers' beliefs about the high yield value of organic rice than non-organic rice. The success of organic rice farming was due to the belief that their crops could be sold at high prices. Moreover, they could also consume healthy food. 
Another interesting point is that farmers were unmotivated to buy tertiary goods, indicated by the lowest score for the activity of "buying tertiary goods" or luxury goods with a score of 2.46 and belonged to the category of "low" motivation. Organic rice farmers in this village were more oriented toward utilizing their income for more critical needs for their families, such as food, clothing, children's school allowances, and health, and various social needs as well.

Table 7. The motivation of organic rice farmers in fulfilling the appreciation needs

\begin{tabular}{|c|c|c|c|c|c|c|c|}
\hline No & $\begin{array}{c}\text { Need for } \\
\text { Appreciation }\end{array}$ & $\begin{array}{c}\text { Score } \\
\text { Category }\end{array}$ & $\begin{array}{l}\text { Score } \\
\text { Range }\end{array}$ & $\begin{array}{l}\text { Number } \\
\text { (people) }\end{array}$ & $\begin{array}{c}\text { Percentage } \\
(\%)\end{array}$ & $\begin{array}{l}\text { Average } \\
\text { Score }\end{array}$ & $\begin{array}{c}\text { Motivation } \\
\text { Category }\end{array}$ \\
\hline \multirow{6}{*}{1} & \multirow{5}{*}{ Improving skills } & $\begin{array}{l}\text { Very Less } \\
\text { Motivated }\end{array}$ & 1 & 0 & 0 & \multirow{5}{*}{4.14} & \multirow{5}{*}{ High } \\
\hline & & Less Motivated & 2 & 0 & 0 & & \\
\hline & & Neutral & 3 & 2 & 5.4 & & \\
\hline & & Motivated & 4 & 28 & 75.7 & & \\
\hline & & Very Motivated & 5 & 7 & 18.9 & & \\
\hline & & Total & & 37 & 100 & & \\
\hline \multirow{6}{*}{2} & \multirow{5}{*}{$\begin{array}{l}\text { Getting to know } \\
\text { new technology }\end{array}$} & $\begin{array}{l}\text { Very Less } \\
\text { Motivated }\end{array}$ & 1 & 0 & 0 & \multirow{5}{*}{4.32} & \multirow{5}{*}{ Very High } \\
\hline & & Less Motivated & 2 & 0 & 0 & & \\
\hline & & Neutral & 3 & 0 & 0 & & \\
\hline & & Motivated & 4 & 25 & 67.6 & & \\
\hline & & Very Motivated & 5 & 12 & 32.4 & & \\
\hline & & Total & & 37 & 100 & & \\
\hline \multirow{6}{*}{3} & \multirow{5}{*}{$\begin{array}{l}\text { Respected by } \\
\text { Others }\end{array}$} & $\begin{array}{l}\text { Very Less } \\
\text { Motivated }\end{array}$ & 1 & 0 & 0 & & \\
\hline & & Less Motivated & 2 & 0 & 0 & \multirow{4}{*}{3.92} & \multirow{4}{*}{ High } \\
\hline & & Neutral & 3 & 9 & 24.3 & & \\
\hline & & Motivated & 4 & 22 & 59.5 & & \\
\hline & & Very Motivated & 5 & 6 & 16.2 & & \\
\hline & & Total & & 37 & 100 & & \\
\hline \multirow{6}{*}{4} & \multirow{5}{*}{ Pride } & $\begin{array}{l}\text { Very Less } \\
\text { Motivated }\end{array}$ & 1 & 0 & 0 & \multirow{5}{*}{4.84} & \multirow{5}{*}{ Very High } \\
\hline & & Less Motivated & 2 & 0 & 0 & & \\
\hline & & Neutral & 3 & 1 & 2.7 & & \\
\hline & & Motivated & 4 & 4 & 10.8 & & \\
\hline & & Very Motivated & 5 & 32 & 86.5 & & \\
\hline & & Total & & 37 & 100 & & \\
\hline \multirow{6}{*}{5} & \multirow{5}{*}{$\begin{array}{l}\text { Buying tertiary } \\
\text { goods }\end{array}$} & $\begin{array}{l}\text { Very Less } \\
\text { Motivated }\end{array}$ & 1 & 1 & 2.7 & \multirow{5}{*}{2.46} & \multirow{5}{*}{ Low } \\
\hline & & Less Motivated & 2 & 22 & 59.5 & & \\
\hline & & Neutral & 3 & 10 & 27 & & \\
\hline & & Motivated & 4 & 4 & 10.8 & & \\
\hline & & Very Motivated & 5 & 0 & 0 & & \\
\hline & \multirow{2}{*}{\multicolumn{2}{|c|}{\begin{tabular}{l|l} 
& Total \\
Total Average Score
\end{tabular}}} & & 37 & 100 & & \\
\hline 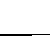 & & & & & & 3.9 & High \\
\hline
\end{tabular}

Score Category:

Very Low: $1.0-1.8$

Low: $1.9-2.6$

Moderate: $2.7-3.4$

High: 3.5 - 4.2

Very High: 4.3 - 5.0 


\subsection{The motivation of Farmers in Fulfilling Self-Actualization Needs}

Self-actualization is the need to realize one's potential to achieve sustainable selfdevelopment and make oneself more creative in the broadest sense of the word. The need for self-actualization was how active the organic rice farmers in influencing or motivating other farmers. Self-actualization could also be seen from the ability of organic rice farmers to increase organic rice production, manufacture organic fertilizers, and expand market networks. The difficulty in emerging victorious from the fierce competition among countries in ASEAN makes peasants do not necessarily keep track of the latest developments in agricultural technology [42]. Farmers could motivate other farmers to farm organic rice. The motivation of organic rice farmers to fulfilling their detailed self-actualization needs is presented in Table 8 .

Table 8 shows that the motivation for the self-actualization needs of organic rice farmers in Gempol Village obtained an average score of 3.5 and was in the "high" category. In more detail, their motivation in activities "motivating other farmers" belonged to the category of very high" motivation with a score of 4.73 . Farmers cared about other farmers as they motivated each other in organic rice farming. Between one and another farmer provided mutual encouragement, mutually reinforcing to make organic rice farmers achieve achievements as the SNI certified of an organic rice producer. It means that each organic rice farmer in Gempol Village was an active farmer, willing to study hard, creative, and innovative, which were their self-actualization.

Meanwhile, the motivation for the self-actualization of organic rice farmers in various other activities, namely "teaching other farmers, increasing production yields, making organic fertilizers and expanding market networks", were in the "moderate" motivation category, with respective scores as presented in Table 8. The category of "moderate" motivation in several activities was understandable, considering that individually organic rice farmers were very busy with their respective activities, thus causing the slow development of the number of organic farmers in Gempol Village. From 2012, only six farmers were interested in farming organic rice in Gempol Village, then increased to 32 farmers in 2016, and 37 farmers in 2020. It is essential to be grateful that internally the 37 organic rice farmers had good solidity, good mental condition, and good faith regarding the superiority of organic rice. The effort to attract conventional farmers to plant organic rice is not easy. On the other hand, organic rice farmers themselves also had many activities. It was why the motivation of organic rice farmers in self-actualization for several activities was categorized as "moderate".

The activity of individual organic farmers in Gempol Village was increasingly visible if seen from the lowest score in "expanding market networks", namely with a score of 3.08, which was still in the category of "moderate" motivation. Most of the organic rice farmers in this village sold their crops to farmer groups. They were less motivated to sell their crops to the market or other parties providing better price opportunities. They stated that they were busy running organic rice farming and had no time to sell their crops to others. Therefore, they did not have the opportunity to expand their market network. However, they have cooperated with various parties in selling organic rice, and they felt that they were getting a reasonable price. Because highly experienced farmers possess better idea about the quality and market potentiality of the organic products and sustainability nature of the organic farming which provides better health and environment for present and future generation [43]. The role of agricultural extension workers should be improved; and they should help control the communication between local leaders and farmers [44]. 
Table 8. The motivation of organic rice farmers in fulfilling self-actualization needs

\begin{tabular}{|c|c|c|c|c|c|c|c|}
\hline No & $\begin{array}{c}\text { Self- } \\
\text { Actualization } \\
\text { Needs }\end{array}$ & $\begin{array}{c}\text { Score } \\
\text { Category }\end{array}$ & $\begin{array}{l}\text { Score } \\
\text { Range }\end{array}$ & $\begin{array}{l}\text { Number } \\
\text { (people) }\end{array}$ & $\begin{array}{c}\text { Percentage } \\
(\%)\end{array}$ & $\begin{array}{l}\text { Average } \\
\text { Score }\end{array}$ & Category \\
\hline \multirow{6}{*}{1.} & \multirow{5}{*}{$\begin{array}{l}\text { Motivate Other } \\
\text { Farmers }\end{array}$} & $\begin{array}{l}\text { Very Less } \\
\text { Motivated }\end{array}$ & 1 & 0 & 0 & \multirow{5}{*}{4.73} & \multirow{5}{*}{ Very High } \\
\hline & & Less Motivated & 2 & 0 & 0 & & \\
\hline & & Neutral & 3 & 0 & 0 & & \\
\hline & & Motivated & 4 & 10 & 27 & & \\
\hline & & Very Motivated & 5 & 27 & 73 & & \\
\hline & & Total & & 37 & 100 & & \\
\hline \multirow{6}{*}{2} & \multirow{5}{*}{$\begin{array}{l}\text { Teaching Other } \\
\text { Farmers }\end{array}$} & $\begin{array}{l}\text { Very Less } \\
\text { Motivated }\end{array}$ & 1 & 0 & 0 & \multirow{5}{*}{3.35} & \multirow{5}{*}{ Moderate } \\
\hline & & Less Motivated & 2 & 7 & 18.9 & & \\
\hline & & Neutral & 3 & 13 & 35.1 & & \\
\hline & & Motivated & 4 & 14 & 37.9 & & \\
\hline & & Very Motivated & 5 & 3 & 8.1 & & \\
\hline & & Total & & 37 & 100 & & \\
\hline \multirow{6}{*}{3} & \multirow{5}{*}{$\begin{array}{l}\text { Increasing } \\
\text { Production } \\
\text { Results }\end{array}$} & $\begin{array}{l}\text { Very Less } \\
\text { Motivated }\end{array}$ & 1 & 0 & 0 & \multirow{5}{*}{3.11} & \multirow{5}{*}{ Moderate } \\
\hline & & Less Motivated & 2 & 1 & 2.7 & & \\
\hline & & Neutral & 3 & 31 & 83.8 & & \\
\hline & & Motivated & 4 & 5 & 13.5 & & \\
\hline & & Very Motivated & 5 & 0 & 0 & & \\
\hline & & Total & & 37 & 100 & & \\
\hline \multirow{6}{*}{4} & \multirow{5}{*}{$\begin{array}{l}\text { Making Organic } \\
\text { Fertilizer }\end{array}$} & $\begin{array}{l}\text { Very Less } \\
\text { Motivated }\end{array}$ & 1 & 0 & 0 & \multirow{5}{*}{3.24} & \multirow{5}{*}{ Moderate } \\
\hline & & Less Motivated & 2 & 14 & 37.9 & & \\
\hline & & Neutral & 3 & 4 & 10.8 & & \\
\hline & & Motivated & 4 & 15 & 40.5 & & \\
\hline & & Very Motivated & 5 & 4 & 10.8 & & \\
\hline & & Total & & 37 & 100 & & \\
\hline \multirow{5}{*}{5} & \multirow{5}{*}{$\begin{array}{c}\text { Expanding } \\
\text { Market Network }\end{array}$} & $\begin{array}{l}\text { Very Less } \\
\text { Motivated }\end{array}$ & 1 & 0 & 0 & \multirow{5}{*}{3.08} & \multirow{5}{*}{ Moderate } \\
\hline & & Less Motivated & 2 & 6 & 16.2 & & \\
\hline & & Neutral & 3 & 24 & 64.9 & & \\
\hline & & Motivated & 4 & 5 & 13.5 & & \\
\hline & & Very Motivated & 5 & 2 & 5.4 & & \\
\hline \multicolumn{4}{|c|}{ Total } & & 37 & 100 & \\
\hline & Total $A$ & erage Score & & & & 3.5 & High \\
\hline
\end{tabular}

Score Category:

Very Low: $1-1.8$

Low: $1.9-2.6$

Moderate: $2.7-3.4$

High: 3.5 - 4.2

Very High: $4.3-5$

\section{Conclusions}

Farmers' motivation to run organic rice farming in Gempol Village belonged to the "high" category. In more detail, four needs consisting of physiological, social, appreciation, and selfactualization, were in the high category. Only the security needs were in the moderate category. To meet the needs of security, organic rice farmers should save some of their 
income. They need to develop capital to invest in the livestock business, whether large or small livestock or poultry. They should have a high need for achievement as well. Training to motivate conventional farmers (non-organic farmers) in Gempol Village is required to persuade them to join organic rice farming, thereby developing the number of members of the organic rice group. The study of Murshed-E-Jahan and Pemsl (2011) on trainings for Bangladeshi small farmers concluded that providing trainings to build the capacity of farmers is more valuable than the provision of financial support [45]. Policy should focus on encouraging farmers to grow organic rice and encourage farmers to join the organic group [46].

\section{References}

1. Aquino, E. C., Shimoguchi, N. N., \& Inaizumi, H. (2019). Comparison of Organic Farmer - Trainers in Japan and the Philippines. International Journal of Environmental and Rural Development, 23.

2. N. A. Etim and E. J. Udoh, Int. J. Sustain. Dev. 91, 1-3 (2020).

3. O. T. Damba, I. G. K. Ansah, S. A. Dankoh, A. Alhassan, G. R. Mullins, K. Yussif, M. S. Taylor, B. K. Tetteh, and M. Appiah-Twumasi, Technol. Soc. 62, (2020).

4. T. G., Int. J. Psychosoc. Rehabil. 24, 2362 (2020).

5. Ataei, P., Gholamrezai, S., Movahedi, R., \& Aliabadi, V. (2020). An analysis of farmers' intention to use green pesticides: The application of the extended theory of planned behavior and health belief model. Journal of Rural Studies.

6. Ashari, J. Sharifuddin, Z. A. Mohammed, and R. Terano, J. Agro Ekon. 34, 35 (2016).

7. P. Pornpratansombat, B. Bauer, and H. Boland, J. Org. Syst. 6(3), 1 (2011).

8. Azam, M. S., \& Shaheen, M. (2018). Decisional factors driving farmers to adopt organic farming in India: a cross-sectional study. International Journal of Social Economics, Volume 46, 562-580.

9. S. Andre, U. Khumairoh, D. Valbuena, and Jeroen C. J. Groot, J. Biol. Agric. Hortic. 36, (2020).

10. Bhubaneswari Bisoyi, B. D. (2017). Organic Farming: A Sustainable Environmental Ingenuity for Biotechnological Intervention towards a Green World. International Journal of Innovative Research in Science, Engineering and Technology, Volume 6, 17900.

11. Cathal Buckley, P. H. (2015). The Role of Differing Farming Motivations on The Adoption of Nutrient Management Practices. International Farm Management Association and Institute of Agricultural Management, Volume 4, 152.

12. Charatsari, C., Koutsouris, A., Lioutas, E. D., Kalivas, A., \& Tsaliki, E. (2017). Promoting Lifelong Learning and Satisfying Farmers' Social and Psychological Needs Through Farmer Field Schools: Views From Rural Greece. Journal of Agricultural \& Food Information, Volume 19, 66-74.

13. S. Suwanmaneepong, C. Kerdsriserm, K. Iyapunya, and U. Wongtragoon, J. Agric. Ext. 24, 71 (2020).

14. Cooper, D.R., \& Schindler, P.S. (2014). Business Research Methods. New York: McGraw-Hill.

15. T. Karyani, F. Arifin, H. Hapsari, and E. Supriyadi, IOP Conf. Ser. Earth Environ. Sci. 306, (2019).

16. T. Dalmiyatun, B. T. Eddy, W. Sumekar, and D. Mardiningsih, IOP Conf. Ser. Earth Environ. Sci. 102, (2018).

17. T. Dalmiyatun, W. D. Prastiwi, and H. Setiyawan, Agric. Soc. Econ. J. 18, 61 (2018).

18. A. Prayoga, J. Agro Ekon. (2016).

19. N. W. Suniti, N. M. Witariadi, and N. W. Siti, Maj. Apl. Ipteks NGAYAH 7, 65 
(2016).

20. H. Mahdavi, M. S. Allahyari, C. A. Damalas, and D. E. S, J. Biol. Agric. Hortic. Vol.36, (2020).

21. Suryono, R. Karsidi, M. Wijaya, and E. S. Rahayu, Int. J. Recent Adv. Multidiscip. Res. 03, 2019 (2016).

22. Dagos, R. A. (2019). Assessment of Lowland Rice-based Organic Farming in Selected Municipalities of Occidental Mindoro, Philippines. International Journal of Agriculture System, Volume 7, 79.

23. Dr. Suresh Patidar, H. P. (2015). A Study of Perception of Farmers towards Organic Farming. International Journal of Application or Innovation in Engineering \& Management (IJAIEM), Volume 4, 269.

24. E.T. Lammerts van bueren, S. L. (2011). The need to breed crop varieties suitable for organic farming, using wheat, tomato and broccoli as examples: A review. Royal Netherlands Society for Agriculture Sciences, Volume 58, 193-205.

25. D. P. Purwakarta, in Dispangtan (Purwakarta, 2017).

26. Hadi Veisi, M. S. (2017). Exploring the motivations and problems of farmers for conversion to organic farming in Iran. International Journal of Agricultural Sustainability, 14.

27. Hariadi, S. S., \& Widhiningsih, D. F. (2020). Young Farmers' Motivation and Participation in Horticultural Organic Farming in Yogyakarta, Indonesia. International Journal of Social Ecology and Sustainable Development, 14.

28. Hiroki Uematsu, A. K. (2012). Organic Farmers or Conventional Farmers: Where's the Money. Ecological Economics, Volume 78, 55-62.

29. W. Prihartanta, J. Adab. Tahun 2015 (2015).

30. Ker Iles, Z. M. (2020). Multi-Dimensional Motivations and Experiences of SmallScale Farmers. International Journal Society and Natural Resources.

31. Kumar, S. (2019). Trends of Organic Farming in Indian Economy. International Journal of Research and Analytical Reviews, 2348-1269.

32. M. M. Dewi, B. W. Utami, and H. Ihsaniyati, J. AGRISTA 4, 104 (2016).

33. D. McClelland, The Achieving Society (Van Nostrand Company Inc, Princenton NJ, 2016).

34. Maslow, A. (1970). Motivation and Personality. New York: Harper dan Row.

35. Sugiyono, Metode Penelitian Kuantitatif, Kualitatif, Dan R\&D (Penerbit Alfabeta, 2012).

36. N. I. Prasetya, Motivasi Wirausaha Petani Dalam Usahatani Padi Organik Di Desa Wijirejo Kecamatan Pandak Kabupaten Bantul Yogyakarta, Universitas Muhammadiyah Yogyakarta, 2015.

37. McClelland D. (1961). The achieving society. Princenton NJ: Van Nostrand Company Inc.

38. Mcgee, J. A. (2015). Does certified organic farming reduce greenhouse gas emissions from agricultural production? Agriculture and Human Values, Volume 32, 255-263.

39. R. A. B. K. Eliza Aprilia, J. Ilm. Mhs. AGROINFO GALUH (2018).

40. T. Andjarwati, J. Ilmu Ekon. Manaj. (2015).

41. C. Yonanda, H. Susilo, and A. Prasetya, J. Adm. Bisnis (2016).

42. Mustari, H. L., \& Sari, W. (2019). The Effect of Achievement Motivation, Fear of Success on the Performance of Farming Women in Ngkaringkaring Village, Baubau City. International Journal of Management Progress, Volume 1, 10-11.

43. Phaibun Yanakittkul, C. A. (2020). A model of farmers intentions towards organic farming: A case study on rice farming in Thailand. CelPress, Volume 6, .

44. Pradhan, M., Tripura, B., Mondal, T. K., Darnnel, R. R., \& Murasing, J. (2017). Factors Influencing the Adoption of Organic Farming by the Farmers of North Ditrict 
of Sikkim. International Journal of Advanced Scientific Research \& Development, Volume 04, 01-07.

45. S. K. Yadav, S. B. (2013). A Review of Organic Farming for Sustainable Agriculture in Northern India. International Journal of Agronomy, Volue 2013, 1.

46. Singh, A. P., \& Singh, R. K. (2020). Socio-Economic Attribute and Attitude of The Farmers Towards Organic Farming in Eastern Uttar Pradesh. International Journal of Agriculture Sciences, Volume 12, 9966. 